\title{
Glycerol Dehydrogenase and Dihydroxyacetone Reductase of a Methylotrophic Yeast, Hansenula ofunaensis
}

\author{
Keiko Yamada and Yoshiki TANI \\ Research Center for Cell and Tissue Culture, Faculty of Agriculture, \\ Kyoto University, Sakyo-ku, Kyoto 606, Japan
}

Received September 9, 1987

\begin{abstract}
$\mathrm{NAD}^{+}$-Linked glycerol dehydrogenase (GDH) activity in Hansenula ofunaensis grown on glycerol was separated into three enzymes by a procedure involving DEAE-cellulose and DEAESephadex A-50 column chromatographies. The oxidative activities toward glycerol of GDH I-1 and GDH I-2 were only detected when the concentration of glycerol was high, while GDH II showed significant activity with a low concentration of glycerol. The $K m$ values for glycerol of GDH I-1, GDH I-2 and GDH II were $0.56 \mathrm{M}, 2.9 \mathrm{~m}$ and $0.16 \mathrm{~m}$, respectively. The $\mathrm{Km}$ values for dihydroxyacetone of GDH I-1, GDH I-2 and GDH II were $0.40 \mathrm{M}, 0.36 \mathrm{~m}$ and $1.7 \mathrm{~mm}$, respectively. The oxidative activities toward 1,2-propanediol of GDH I-1 and GDH II were 0.37- and 1.5-fold those toward glycerol, respectively. GDH I-2 showed significant oxidative activity toward ethanol, while GDH I-1 and GDH II showed no such activity. GDH I-2 was identical to dihydroxyacetone reductase induced in methanol-grown cells.
\end{abstract}

Isozymes of glycerol dehydrogenase (GDH) have been demonstrated in Geotrichum candidum $^{1)}$ and Klebsiella pneumoniae. ${ }^{2)}$ It was also found that Schizosaccharomyces pombe produced four pyridine nucleotide-linked GDHs (or triose reductases). ${ }^{3)} S$. pombe $e^{4,5)}$ and Candida valida $^{6}$ are known to utilize glycerol through $\mathrm{NAD}^{+}$-linked GDH. GDH of $K$. pneumoniae has been used for anaerobic glycerol dissimilation. ${ }^{7)}$

Previously, we classified methylotrophic yeasts into three groups with regard to the primary enzyme involved in glycerol dissimilation. ${ }^{89}$ Hansenula ofunaensis has the oxidative pathway involving GDH, but not the phosphorylative pathway involving glycerol kinase. The activity to oxidize glycerol to dihydroxyacetone was induced only by glycerol, i.e., not by methanol. On the other hand, an enzyme which preferably reduced dihydroxyacetone to glycerol was detected in the methanol medium and designated as dihydroxyacetone reductase. ${ }^{10,11)}$ Dihydroxyacetone is an intermediate in the methanol metabolism of methylotrophic yeasts. ${ }^{12)}$ Thus,
GDH could be a key enzyme between the metabolic pathways for methanol and glycerol. In the present paper, a comparative study of GDHs in $H$. ofunaensis grown on glycerol will be reported.

\section{MATERIALS AND METHODS}

Cultivation and enzyme assay. H: ofunaensis was cultivated in the glycerol medium and harvested as described previously. ${ }^{10)}$ Enzyme activity and protein determinations through out the enzyme preparation were carried out under the same conditions as given previously. ${ }^{10}$ The conductivity of the eluate on column chromatography was determined with a CD-35MII conductivity meter (M\&S Instruments) at $10^{\circ} \mathrm{C}$. For measuring the $K m$ values for dihydroxyacetone and $\mathrm{NADH}$, an assay system containing $100 \mathrm{~mm}$ potassium phosphate buffer (KPB), $\mathrm{pH} 6.0,0.5 \mathrm{M}$ dihydroxyacetone for GDH I-1 and GDH I-2 or $1.3 \mathrm{~mm}$ dihydroxyacetone for GDH II, $0.1 \mathrm{~mm} \mathrm{NADH}$ for $\mathrm{GDH}$ I- 1 or $0.2 \mathrm{~mm} \mathrm{NADH}$ for GDH I-2 and GDH II, and the enzyme, in a total volume of $0.6 \mathrm{ml}$, was used, the concentrations of dihydroxyacetone and NADH being varied. To measure the $\mathrm{Km}$ values for glycerol and $\mathrm{NAD}^{+}$, an assay system containing $100 \mathrm{mM} \mathrm{NH}_{4} \mathrm{Cl}-\mathrm{NH}_{4} \mathrm{OH}, \mathrm{pH} 9.0$, for GDH I-1 or $100 \mathrm{~mm} \mathrm{KPB}$, pH 8.0, for GDH I-2 and GDH II, 2 mM NAD ${ }^{+}, 0.5 \mathrm{M}$ glycerol and the enzyme, in a total volume of $0.6 \mathrm{ml}$, was used, the concentrations of 
glycerol and $\mathrm{NAD}^{+}$being varied.

\section{RESULTS}

Separation of GDH in glycerol-grown cells

All operations were performed at $0 \sim 10^{\circ} \mathrm{C}$, and $\mathrm{KPB}, \mathrm{pH} 7.0$ (buffer $\mathrm{A}$ ), and Tris $\cdot \mathrm{HCl}$ buffer, $\mathrm{pH} 7.0$ (buffer $\mathrm{B}$ ) and $\mathrm{pH} 7.7$ (buffer C), containing $1 \mathrm{~mm}$ dithiothreitol, were used.

Glycerol-grown cells from 5-1 of culture broth were suspended in about $630 \mathrm{ml}$ of $0.01 \mathrm{~m}$ buffer $\mathrm{A}$. The suspended cells were disrupted and the supernatant solution was obtained as described previously. ${ }^{8)}$

The cell-free extractt was then applied onto a DEAE-cellulose column $(5.0 \times 20 \mathrm{~cm})$ equili-

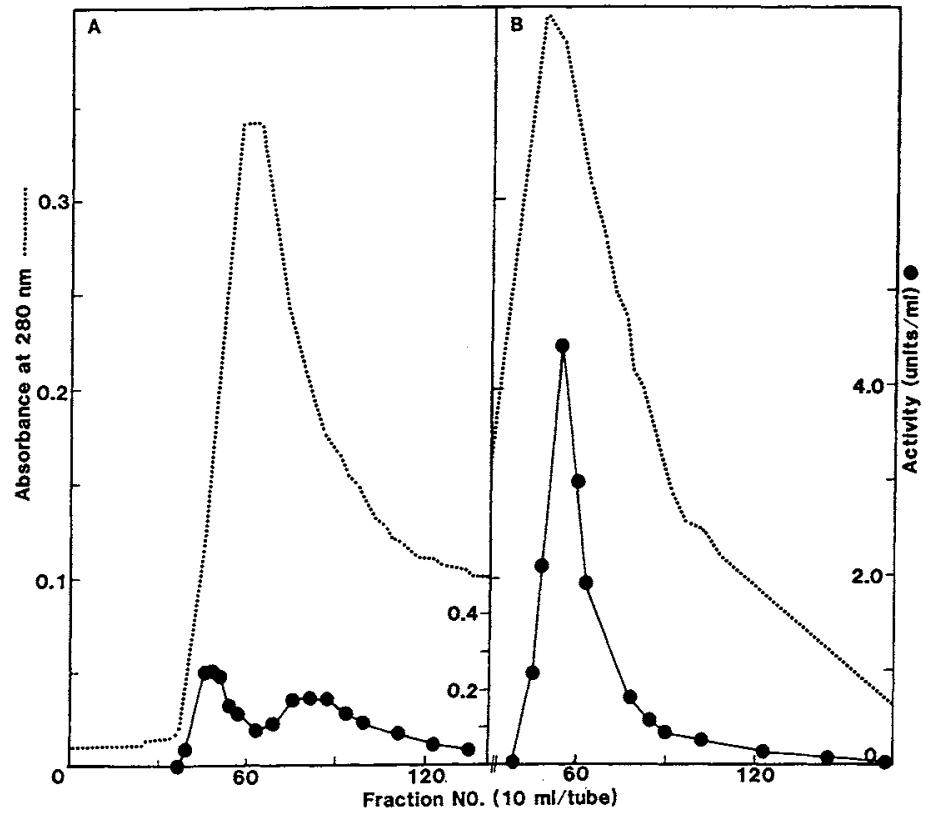

FrG. 1. Separation of GDH on DEAE-Cellulose Column Chromatography.

Elution was performed as described in text at fiow rates of $130 \mathrm{ml} / \mathrm{hr}$ (A) and $180 \mathrm{ml} / \mathrm{hr}$ (B). Eluates were collected in $10-\mathrm{ml}$ fractions.

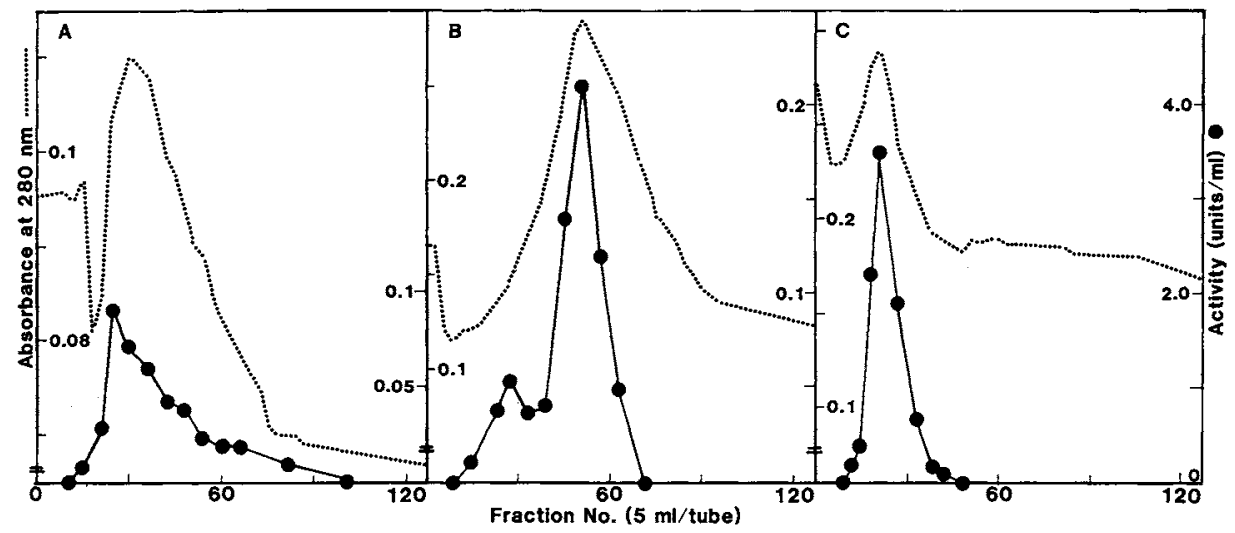

FIG. 2. Separation of GDH on DEAE-Sephadex A-50 Column Chromatography.

Elution was performed as described in text at flow rates of $120 \mathrm{ml} / \mathrm{hr}(\mathrm{A}), 91 \mathrm{ml} / \mathrm{hr}(\mathrm{B})$ and $100 \mathrm{ml} / \mathrm{hr}(\mathrm{C})$. Eluates were collected in 5-ml fractions. 
brated with $0.01 \mathrm{M}$ buffer $\mathrm{A}$. The enzymes were eluted with a concentration gradient of buffer $\mathrm{A}(0.03 \sim 0.07 \mathrm{M})$ after washing with $0.03 \mathrm{M}$ buffer A (Fig. 1A), and then with one of from $0.1 \mathrm{M}$ buffer A containing $0.1 \mathrm{M} \mathrm{KCl}$ to $0.1 \mathrm{M}$ buffer A containing $0.2 \mathrm{M} \mathrm{KCl}$ (Fig. 1B) after washing with $0.1 \mathrm{M}$ buffer $\mathrm{A}$ containing $0.1 \mathrm{M} \mathrm{KCl}$. As shown in Fig. 1A, GDH activity was separated into two fractions, which were designated as GDH I-1 and GDH I-2, in order of elution. In Fig. 1B, one peak of GDH activities of GDH I-1, GDH I-2 and GDH II GDH II. The conductivities at the peaks of the activities of GDH-I-1, GDH I-2 and GDH II were $9.9 \mathrm{mmho}, 13 \mathrm{mmho}$ and $36 \mathrm{mmho}$, respectively. Each fraction was concentrated by ultrafiltration with a collodion bag.

The fractions containing GDH I-1 and GDH I-2 obtained on DEAE-cellulose column chromatography were applied onto a DEAESephadex A-50 column $(1.8 \times 20 \mathrm{~cm})$, respec- tively, which had been equilibrated with $0.01 \mathrm{M}$ buffer B. After washing with $0.1 \mathrm{M}$ buffer B, GDH I-1 was eluted with a gradient system

\section{Table I. Purification Of GDH}

An assay system containing $100 \mathrm{~mm} \mathrm{KPB}(\mathrm{pH} 6.0$ ), $0.17 \mathrm{~mm} \mathrm{NADH}, 0.1 \mathrm{~m}$ dihydroxyacetone and each enzyme fraction was used for measuring NADH-dependent dihydroxyacetone reduction.

\begin{tabular}{lccccc}
\hline Fraction & $\begin{array}{c}\text { Total } \\
\text { activity } \\
\text { (units) }\end{array}$ & $\begin{array}{c}\text { Total } \\
\text { protein } \\
\text { (mg) }\end{array}$ & $\begin{array}{c}\text { Specific } \\
\text { activity } \\
\text { (units/mg) }\end{array}$ & $\begin{array}{c}\text { Yield } \\
\text { ( })\end{array}$ & Fold \\
\hline Cell-free extract & 1,300 & 3,500 & 0.37 & 100 & 1 \\
DEAE-Cellulose & & & & & \\
GDH I-1 & 32 & 22 & 1.5 & 2.5 & 4.1 \\
GDH I-2 & 30 & 45 & 0.67 & 2.3 & 1.8 \\
GDH II & 620 & 79 & 7.8 & 48 & 21 \\
DEAE-Sephadex A-50 & & & & \\
GDH I-1 & 9.4 & 2.2 & 4.3 & 0.72 & 12 \\
GDH I-2 & 12 & 14 & 0.86 & 0.90 & 2.3 \\
GDH II & 180 & 5.7 & 32 & 14 & 86 \\
\hline
\end{tabular}

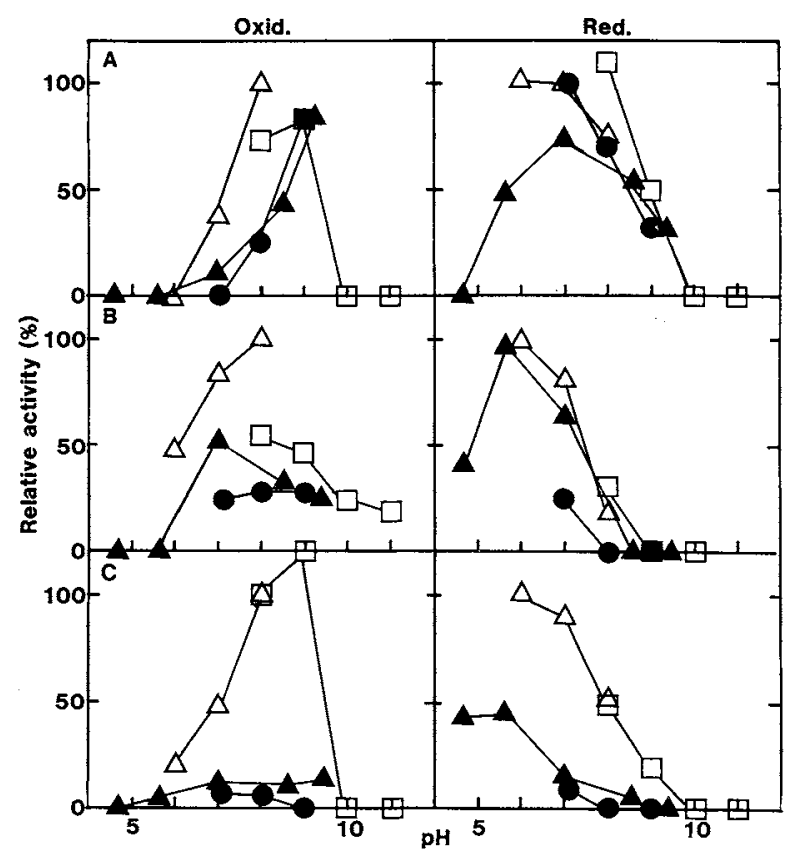

FIG. 3. Effect of $\mathrm{pH}$ on GDH Activity.

For measuring the oxidation of glycerol, the assay mixture contained $100 \mathrm{~mm}$ buffer, $1 \mathrm{~mm} \mathrm{NAD}+0.5 \mathrm{M}$ glycerol and the enzyme. The reduction was measured with an assay mixture containing $100 \mathrm{~mm}$ buffer, $0.1 \mathrm{~mm}$ NADH for GDH I-1 and GDH II or $0.17 \mathrm{~mm} \mathrm{NADH}$ for GDH I-2, $0.5 \mathrm{M}$ dihydroxyacetone for GDH I-1 and GDH I-2 or $0.0013 \mathrm{M}$ dihydroxyacetone for GDH II, and the enzyme. $\mathrm{NH}_{4} \mathrm{Cl}-\mathrm{NH}_{4} \mathrm{OH}(\mathrm{pH} 8 \sim 11)(\square)$; $\mathrm{K}_{2} \mathrm{HPO}_{4}-\mathrm{KH}_{2} \mathrm{PO}_{4}(\mathrm{pH} 6 \sim 8)(\triangle)$; Tris $\cdot \mathrm{HCl}(\mathrm{pH} 7.2 \sim 9.0)(\bullet)$; and Tris-maleate $(\mathrm{pH} 4.7 \sim 9.4)(\Delta)$ were used as buffers. 
from 0 to $0.1 \mathrm{M} \mathrm{KCl}$ in $0.1 \mathrm{M}$ buffer $\mathrm{B}$, and GDH I-2 with one from 0 to $0.16 \mathrm{M} \mathrm{KCl}$ in $0.1 \mathrm{M}$ buffer $\mathrm{B}$, respectively (Figs. $2 \mathrm{~A}$ and $2 \mathrm{~B}$ ). GDH II was applied onto a DEAE-Sephadex A-50 column $(1.8 \times 20 \mathrm{~cm})$ equilibrated with $0.01 \mathrm{M}$ buffer $\mathrm{C}$. After washing with $0.1 \mathrm{M}$ buffer $\mathrm{C}$ containing $0.2 \mathrm{M} \mathrm{KCl}$, GDH II was eluted with a gradient from $0.2 \mathrm{M}$ to $0.8 \mathrm{M} \mathrm{KCl}$ in $0.1 \mathrm{M}$ buffer $\mathrm{C}$ (Fig. 2C). The peaks of the activities of GDH I-1, GDH I-2 and GDH II were eluted at conductivities of $11.6 \mathrm{mmho}$, $16 \mathrm{mmho}$ and $35 \mathrm{mmho}$, respectively, under the conditions employed. The two peaks in Fig. 2B consist of GDH I-2, the main component, and GDH I-1, presented the minor component. A summary of the purification procedure is presented in Table $\mathrm{I}$.

After DEAE-Sephadex A-50 column chromatography, GDH I-1, GDH I-2 and GDH II were found to have been purified 12-fold, 2.3fold and 86-fold, compared with the cell-free extract, respectively, and were used for the following experiments.

\section{Characterization of GDH I-I, GDH I-2 and GDH II}

1) Effect of $p H$ on $G D H$ activity. Variation in the GDH activity was investigated between pH 5.2 and 11 (Fig. 3). The maximum activity of GDH I-1 in the forward reaction was observed at $\mathrm{pH} 8.0 \sim 9.0$, while that in the reverse reaction was observed at $\mathrm{pH} 6.0 \sim 7.0$ (Fig. 3A). The type of buffer used had little effect on the activities.

The optimum $\mathrm{pH}$ of GDH I-2 for the oxidation of glycerol was 8.0 and that for the reduction of dihydroxyacetone was 6.0 , as shown in Fig. 3B. GDH I-2 activity was inhibited by Tris $\cdot \mathrm{HCl}$ buffer.

The oxidation of glycerol to dihydroxyacetone by GDH II was highest at $\mathrm{pH} 9.0$, whereas the reduction of dihydroxyacetone was highest at $\mathrm{pH} 6.0$ (Fig. 3C). Tris $\cdot \mathrm{HCl}$ and Tris-maleate buffers inhibited both the oxidation of glycerol and the reduction of dihydroxyacetone by GDH II.

2) Effect of temperature on GDH activity. The activity was measured at various temperatures between $5^{\circ} \mathrm{C}$ and $65^{\circ} \mathrm{C}$ at pH 6.0 (Fig. 4). The optimum temperature of GDH I-1 was $35^{\circ} \mathrm{C}$ (Fig. 4A). GDH I-1 was incubated at various temperatures for $20 \mathrm{~min}$ and then its residual activity was determined. GDH I-1 did not retain any activity at $45^{\circ} \mathrm{C}$ (Fig. 5A).

The reaction rate of GDH I-2 was maximum at $55^{\circ} \mathrm{C}$ (Fig. 4B). The residual activity of GDH I-2 was $0 \%$ after incubation at over $55^{\circ} \mathrm{C}$ and $90 \%$ at $45^{\circ} \mathrm{C}$ (Fig. 5B). The activity

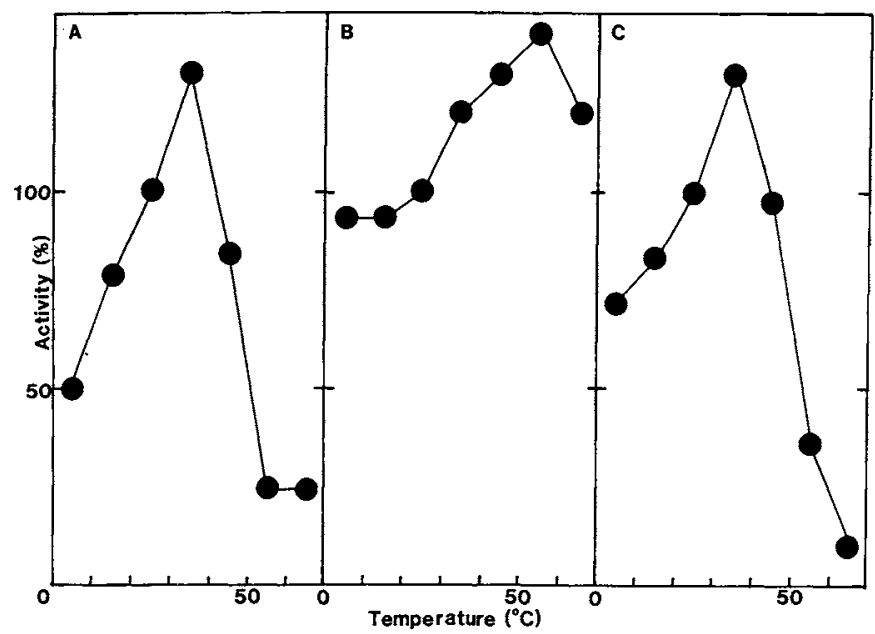

FIG. 4. Temperature Dependency.

An assay system containing $100 \mathrm{~mm} \mathrm{KPB}, \mathrm{pH} 6.0,0.1 \mathrm{~mm}$ NADH, 0.5 $\mathrm{M}$ dihydroxyacetone for GDH I-1 and GDH I-2 or $0.013 \mathrm{M}$ dihydroxyacetone for GDH II, and the enzyme was used at various temperatures. 


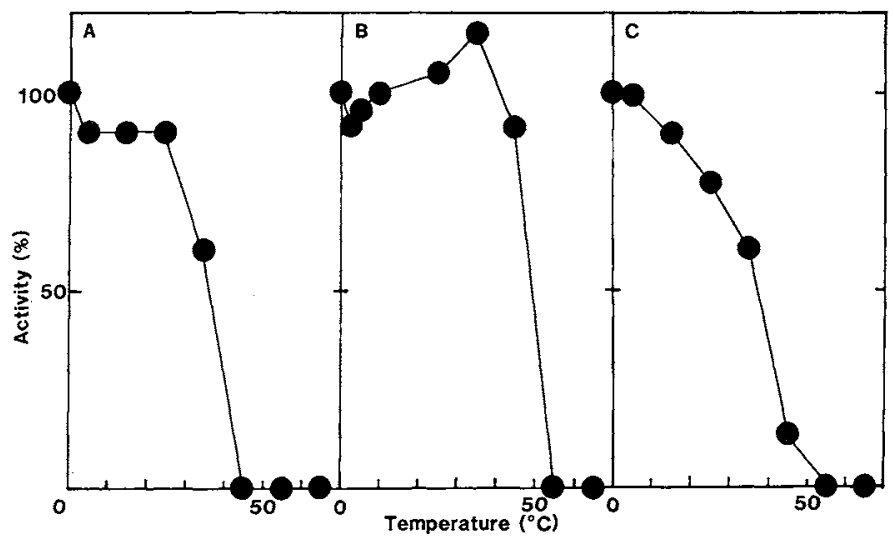

FIG. 5. Thermal Stability.

The enzyme activity was determined after incubation at each temperature for $20 \mathrm{~min}$. An assay system containing $100 \mathrm{~mm} \mathrm{KPB}(\mathrm{pH} 6.0$ ), $0.1 \mathrm{~mm}$ NADH for GDH I-1 or $0.17 \mathrm{~mm}$ NADH for GDH I-2, $0.5 \mathrm{~m}$ dihydroxyacetone for GDH I-1 or $0.1 \mathrm{M}$ dihydroxyacetone for GDH I-2, and the enzyme was used. An assay

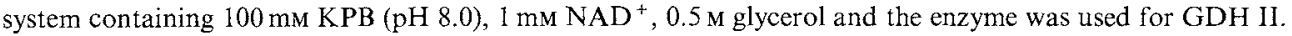

Table II. Substrate Specificities of GDH I-1, GDH I-2 AND GDH II IN THE FORWARD AND REVERSE REACTIONS

For measuring the oxidation of various substrates, an assay system containing $100 \mathrm{~mm} \mathrm{KPB}(\mathrm{pH} 8.0), 1 \mathrm{~mm}$ $\mathrm{NAD}^{+}, 0.5 \mathrm{M}$ substrate and the enzyme was used for GDH I-1, GDH I-2 and GDH II. No significant activity toward $0.5 \mathrm{M}$ ethylene glycol, $0.5 \mathrm{M}$ lactic acid and $0.17 \mathrm{M}$ glycerol 3-phosphate was observed. For measuring the reduction of various substrates, an assay system containing $100 \mathrm{~mm} \mathrm{KPB} \mathrm{(pH} \mathrm{6.0),} \mathrm{0.1} \mathrm{mM} \mathrm{NADH,} \mathrm{0.13} \mathrm{m} \mathrm{sub-}$ strate for GDH I-1 and GDH I-2 or $0.013 \mathrm{M}$ substrate for GDH 1I, and the enzyme was used. These GDHs did not act on DL-glyceraldehyde.

\begin{tabular}{lrcc}
\hline & \multicolumn{3}{c}{ Relative activity $\%$} \\
\cline { 2 - 4 } & GDH I-1 & GDH I-2 & GDH II \\
\hline Oxidation & & & \\
Glycerol & 100 & $<1$ & 100 \\
1,2-Propanediol & 37 & 100 & 150 \\
Ethanol & 0 & 20 & 0 \\
Reduction & 100 & 100 & 100 \\
Dihydroxyacetone & 0 & 180 & 48 \\
Methylglyoxal & 0 & 230 & 33 \\
Acetol & - & & \\
\hline
\end{tabular}

of $\mathrm{GDH} \mathrm{I}-2$ was more stable at 15 to $40^{\circ} \mathrm{C}$ than at 2.5 to $5^{\circ} \mathrm{C}$.

As shown in Fig. 4C, GDH II showed the highest activity at $35^{\circ} \mathrm{C}$. The residual activity of $\mathrm{GDH}$ II was $13 \%$ at $45^{\circ} \mathrm{C}$ (Fig. $5 \mathrm{C}$ ).
3) Substrate specificity. GDH I-1 was found to exhibit a rather narrow substrate specificity (Table II). 1,2-Propanediol was dehydrogenated at $37 \%$ the rate for glycerol by GDH I-1. Other substrates tested were not oxidized by GDH I-1. GDH I-1 did not reduce acetol, DLglyceraldehyde or methylglyoxal.

GDH I-2 showed a broad substrate specificity. Not only glycerol and 1,2-popanediol but also ethanol were active substrates for GDH I-2. When the activity toward 1,2-propanediol was taken as $100 \%$, those toward glycerol and ethanol were under $1 \%$ and about $20 \%$, respectively. GDH I-2 could reduce methylglyoxal and acetol more rapidly than dihydroxyacetone. DL-Glyceraldehyde was inert as a substrate.

In the elution patterns of GDH II on DEAE-cellulose and Sepharose 6B column chromatographies, the peak corresponding to the dehydrogenase activity toward glycerol overlapped with that corresponding the activity toward 1,2-propanediol. The activity of GDH II toward 1,2-propanediol was 1.5-fold that toward glycerol. GDH II did not oxidize other compounds tested than glycerol and 1,2propanediol, as in the case of GDH I-1. Methylglyoxal and acetol were reduced by GDH II at $48 \%$ and $33 \%$ the rate for dihy- 


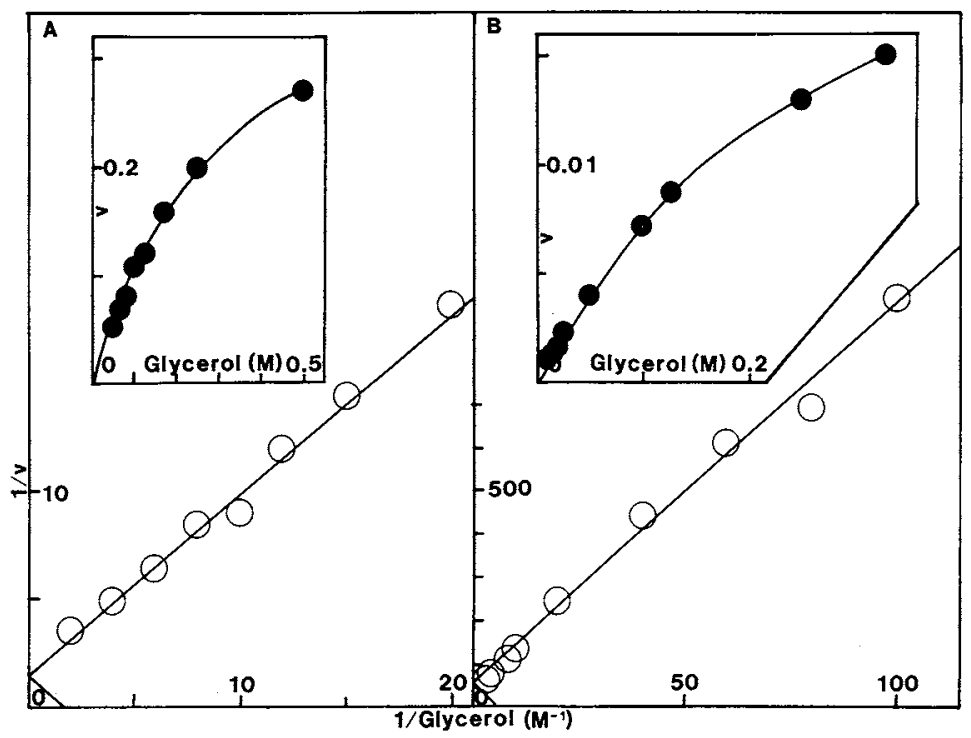

FIG. 6. Relationship between the Initial Reaction Velocities of GDH I-1 (A) and GDH II (B) and the Glycerol Concentration.

The enzyme activity was determined as described under Materials AND METHODS.

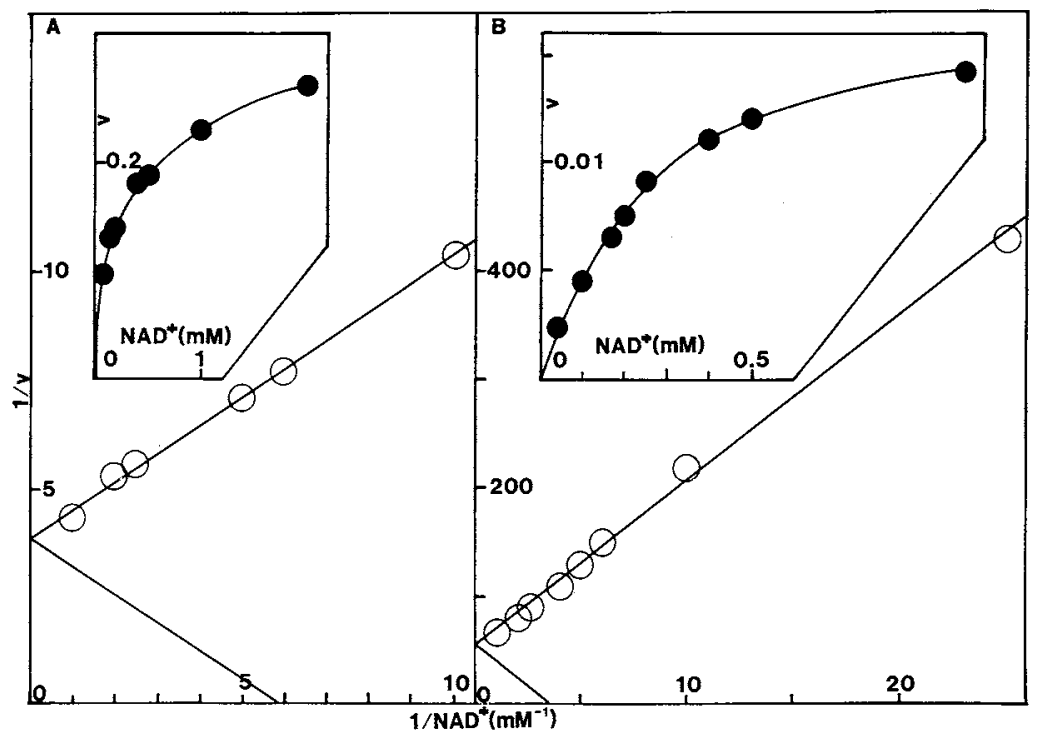

Fig. 7. Relationship between the Initial Reaction Velocities of GDH I-1 (A) and GDH II (B) and the $\mathrm{NAD}^{+}$Concentration.

The enzyme activity was determined as described under MATERIALS AND METHODS.

droxyacetone, respectively.

4) $K m$ values. The $K m$ values of GDH I- 1 for glycerol and $\mathrm{NAD}^{+}$were $0.56 \mathrm{M}$ and $0.17 \mathrm{~mm}$, respectively, at $\mathrm{pH} 9.0$ (Figs. $6 \mathrm{~A}$ and $7 \mathrm{~A}$ ). The $\mathrm{Km}$ values of GDH I-1 for dihydroxyacetone and NADH were $0.40 \mathrm{M}$ and $0.025 \mathrm{~mm}$, respectively, at pH 6.0 (Figs. $8 \mathrm{~A}$ and $9 \mathrm{~A}$ ).

The $\mathrm{Km}$ values of GDH I-2 for glycerol and $\mathrm{NAD}^{+}$were $2.9 \mathrm{M}$ and $0.029 \mathrm{~mm}$. As shown in Figs. 8B and 9B, the $K m$ values of GDH I-2 for 


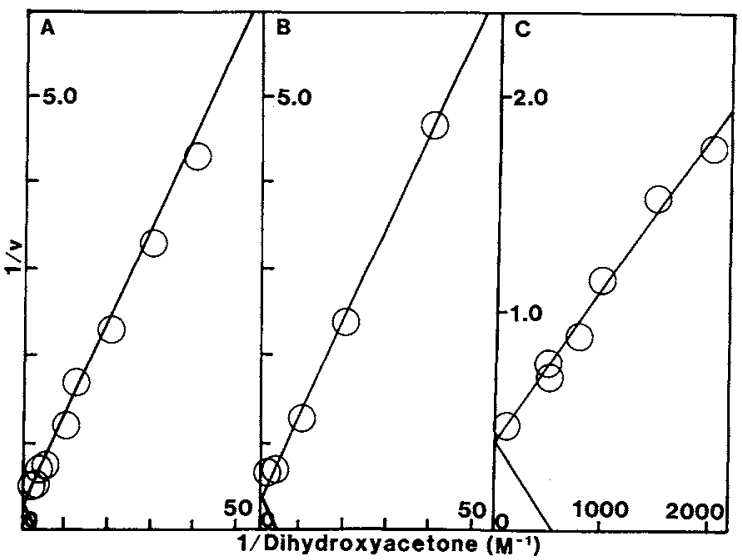

FIG. 8. Relationship between the Initial Reaction Velocities of GDH I-1 (A), GDH I-2 (B) and GDH II (C) and the Dihydroxyacetone Concentration.

The enzyme activity was determined as described under Materials AND METHODS.

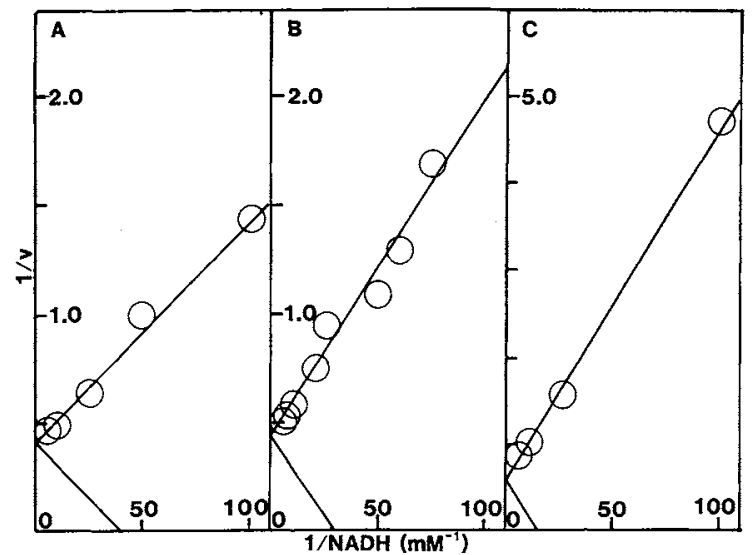

FIG. 9. Relationship between the Initial Reaction Velocities of GDH I-1 (A), GDH I-2 (B) and GDH II (C) and the NADH Concentration.

The enzyme activity was determined as described under MATERIALs AND METHODS.

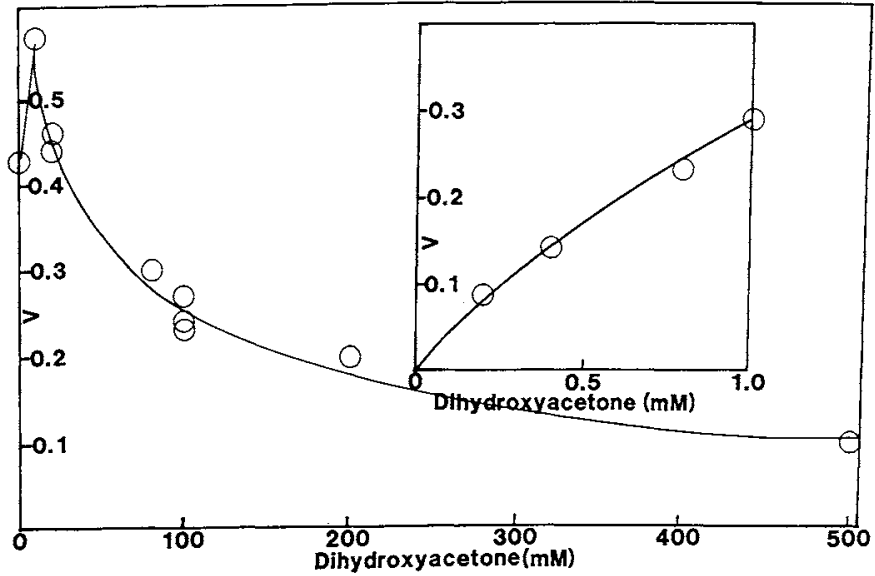

Fig. 10. Effect of the Concentration on the Reduction of Dihydroxyacetone by GDH II.

The enzyme activity was determined with an assay system containing $100 \mathrm{mM} \mathrm{KPB} \mathrm{(pH} \mathrm{6.0),} \mathrm{0.17} \mathrm{mM} \mathrm{NADH,}$ dihydroxyacetone at various concentrations and the enzyme. 
dihydroxyacetone and NADH were $0.36 \mathrm{~m}$ and $0.033 \mathrm{~mm}$, respectively.

The apparent $K m$ values of GDH II for glycerol and $\mathrm{NAD}^{+}$were $0.16 \mathrm{M}$ and $0.28 \mathrm{~mm}$, respectively (Figs. 6B and $7 \mathrm{~B}$ ). The apparent $\mathrm{Km}$ values for dihydroxyacetone and $\mathrm{NADH}$ were $1.7 \mathrm{~mm}$ and $0.063 \mathrm{~mm}$, respectively, at pH 6.0 (Figs. 8C and 9C). Dihydroxyacetone caused inhibition at a concentration of more than $10 \mathrm{~mm}$ (Fig. 10). When another system containing $100 \mathrm{mM} \mathrm{NH}_{4} \mathrm{Cl}-\mathrm{NH}_{4} \mathrm{OH}, \mathrm{pH} 9.0$, $1 \mathrm{~mm} \mathrm{NAD}^{+}$and $0.5 \mathrm{~m}$ glycerol, and the enzyme, was used, and the concentrations of glycerol and $\mathrm{NAD}^{+}$were varied, the $\mathrm{Km}$ values for glycerol and $\mathrm{NAD}^{+}$were $83 \mathrm{~mm}$ and $0.034 \mathrm{~mm}$, respectively. The activity under the latter conditions was unstable.

\section{DISCUSSION}

H. ofunaensis grown on glycerol was found to produce three types of GDH. These three enzymes were characterized in this study.

GDH I-2 and GDH II were inhibited by Tris. Such inhibition has been shown for 1,2propanediol dehydrogenase from cells of a methanol-utilizing bacterium, Microcyclus eburneus, grown on 1,2-propanediol, ${ }^{13)}$ and GDH of $C$. valida. ${ }^{14)}$ GDH I-2 showed the highest activity after treatment at $35^{\circ} \mathrm{C}$ (Fig. 5). It was reported that a rat liver acetyl-CoA hydrolase shows the extreme cold lability, i.e., the enzymatically active dimeric and tetrameric forms dissociate into the inactive monomer at low temperature, and the activity is recovered on treatment at $37^{\circ} \mathrm{C}^{15)} \mathrm{GDH} \mathrm{I-2}$ could be considered to have such cold lability, although activation at $35^{\circ} \mathrm{C}$ is also possible.

The activities of GDH I-1, GDH I-2 and GDH II in the forward and reverse reactions with other substrates than glycerol and dihydroxyacetone were different. The activity against each substrate in Table II shows the same elution pattern in DEAE-cellulose column chromatography. GDH I-1 and GDH II did not oxidize ethanol. The enzymes of $G$. candidum are also specific for 2-hydroxy compounds. ${ }^{1)}$ GDHs of $K$. pneumoniae, Mucor javanicus $^{16)}$ and Cellulomonas sp. NT 306017) showed detectable activities toward ethylene glycol. Glycerol 3-phosphate was a substrate for GDH of Cellulomonas sp. NT $3060 .{ }^{17)}$ Our enzymes did not oxidize ethylene glycol or glycerol 3-phosphate. Acetol was reduced by GDH I-2 and GDH II $230 \%$ and $33 \%$ the rate for dihydroxyacetone, respectively. GDH I-1 did not reduce acetol. Acetol was active as dihydroxyacetone in an Escherichia coli mutant. ${ }^{18)}$ Acetol is an oxidized product of 1,2-propanediol. GDH I-2 and GDH II oxidized 1,2-propanediol more rapidly than glycerol. The oxidation rate for 1,2-propanediol of GDH I-1 was 37\% that for glycerol. G. candidum utilized 1,2-propanediol, ${ }^{19)}$ and its GDH activity was induced by 1,2-propanediol. $H$. ofunaensis produced GDH II on the addition of 1,2-propanediol to the methanol medium, in spite of there being no growth on 1,2-propanediol as a carbon source.

Each enzyme showed different $K m$ values for glycerol and dihydroxyacetone, and these $K m$ values were high. $C$. valida ${ }^{6)}$ and $S$. pom$b e{ }^{4.5)}$ are known to utilize glycerol through GDH. The $K m$ values for glycerol were $58 \mathrm{~mm}$ for C. valida ${ }^{14)}$ and $0.5 \mathrm{~mm}$ for $S$. pombe ${ }^{20)}$ The $K m$ values for dihydroxyacetone were $0.77 \mathrm{~mm}$ for C. valida ${ }^{14)}$ and $0.06 \mathrm{~mm}$ for $S$. pombe. ${ }^{20)}$ The $K m$ values of GDH for glycerol and dihydroxyacetone were $3.7 \mathrm{~mm}$ and $1.2 \mathrm{~mm}$, while those of another GDH, of $G$. candidum were $3.4 \mathrm{~mm}$ and $1.0 \mathrm{~mm}$, respectively. ${ }^{1)}$ The $K m$ values for glycerol of GDH from $K$. pneumoniae were $1.7 \times 10^{-2} \mathrm{M}$ and $5.6 \times 10^{-3} \mathrm{M}$ in the presence of $3.3 \mathrm{~mm}$ and $33 \mathrm{mM} \mathrm{NH}_{4} \mathrm{Cl}$, respectively. ${ }^{21)}$ The $\mathrm{Km}$ values for glycerol of GDH II were $1.6 \times 10^{-1} \mathrm{M}$ and $8.3 \times 10^{-2}$, in the absence and presence of $100 \mathrm{mM} \mathrm{NH}_{4}{ }^{+}$, respectively. The $K m$ value for dihydroxyacetone of GDH of $K$. pneumoniae was $0.13 \mathrm{~mm}$. The reduction of dihydroxyacetone was inhibited by the substrate at concentrations of above $0.4 \mathrm{~mm}^{22)}$ The reduction by GDH II of $H$. ofunaensis was inhibited by dihydroxyacetone at a concentration of more than $10 \mathrm{~mm}$, while the $K m$ value for dihy- 
droxyacetone of GDH II was $1.7 \mathrm{~mm}$.

Gartner and Kopperschlager determined that the low affinity for glycerol of GDH of $C$. valida prevented the excessive formation of dihydroxyacetone phosphate which could lead to the toxic production of methylglyoxal. ${ }^{14)} \mathrm{K}$. pneumoniae had two types of GDH, one of which may be responsible for anaerobic glycerol dissimilation. The physiological function of the other minor GDH is unknown. The oxidative pathway of glycerol dissimilation in $K$. pneumoniae was induced irrespective of the glycerol concentration in the growth medium under anaerobic conditions. Under aerobic conditions the oxidative pathway was induced when glycerol was abundant, and the phosphorylative pathway was induced when glycerol was limited. The $K m$ for glycerol was about $10^{-3} \mathrm{~mm}$ for glycerol kinase and $20 \mathrm{~mm}$ for GDH. Hueting et al. speculated that the organism possesses this type of regulatory mechanism in order to prevent traumatic effects due to unrestricted uptake of glycerol and intracellular accumulation of phosphorylated derivatives. ${ }^{23)}$ Methylglyoxal was also found in methylotrophic yeasts. ${ }^{24)} H$. ofunaensis grown on glycerol of methanol showed high dihydroxyacetone kinase activity. $H$. ofunaensis might dissimilate glycerol and control the level of a toxic compound, by using these GDHs which have various affinities for glycerol and dihydroxyacetone.

$H$. ofunaensis produced three types of GDH when grown on glycerol. Dihydroxyacetone reductase from methanol-grown cells gave the same experimental data as GDH I-2 from glycerol-grown cells. ${ }^{10)}$ The $K m$ values for glycerol of dihydroxyacetone reductase from H. ofunaensi $i^{10)}$ and Dunaliella parva ${ }^{25)}$ were $2.9 \mathrm{M}$ and $1.4 \mathrm{M}$, respectively. Dihydroxyacetone reductase of Dunaliella parva is used for glycerol production. ${ }^{26)}$ The role of this enzyme in methylotrophic yeasts will be elucidated in a further study.

\section{REFERENCES}

1) N. Itoh, Agric. Biol. Chem., 46, 3029 (1982).

2) J. C.-T. Tang, R. G. Forage and E. C. C. Lin, J. Bacteriol., 152, 1169 (1982).

3) Y.-C. Kong, J. W. May and J. H. Marshall, J. Gen. Microbiol., 131, 1571 (1985).

4) J. W. May and J. Sloan, J. Gen. Microbiol., 123, 183 (1981).

5) C. Gancedo, A. Llobell, J.-C. Ribas and F. Luchi, Eur. J. Biochem., 159, 171 (1986).

6) K. H. Hofmann and W. Babel, "Abhandlungen der Akademie der Wissenschaften der DDR N3," Akademie-Verlag, Berlin, 1981, pp. 229 234 .

7) E. C. C. Lin, Ann. Rev. Microbiol., 30, 535 (1976).

8) Y. Tani and K. Yamada, FEMS Microbiol. Lett., 40, 151 (1987).

9) Y. Tani and K. Yamada, Agric. Biol. Chem., 51, 1927 (1987)

10) K. Yamada and Y. Tani, Agric. Biol. Chem., 51, 2629 (1987).

11) K. Yamada and Y. Tani, Agric. Biol. Chem., 51, 2401 (1987).

12) Y. Tani, in "Methylotrophs: Microbiology, Biochemistry and Genetics," ed. by C. T. Hou, CRC Press, Boca Raton, FL, 1984, pp. 55 85.

13) N. Nishio, T. Kawagishi, R. Matsuno and $T$. Kamikubo, Agric. Biol. Chem., 42, 1095 (1978).

14) G. Gartner and G. Kopperschlager, J. Gen. Microbiol., 130, 3225 (1984).

15) F. Isohashi, Vitamins (Japan), 60, 437 (1986).

16) E. Hochuli, K. E. Taylor and H. Dutler, Eur. J. Biochem., 75, 433 (1977).

17) H. Yamada, A. Nagao, H. Nishise and Y. Tani, Agric. Biol. Chem., 46, 2333 (1982).

18) C.-T. Tang, F. E. Ruch and E. C. C. Lin, $J$. Bacteriol., 140, 182 (1979).

19) N. Itoh and K. Umeda, Agric. Biol. Chem., 46, 2159 (1982).

20) J. H. Marshall, J. W. May and J. Sloan, J. Gen. Microbiol., 131, 1581 (1985).

21) E. C. C. Lin and B. Magasanik, J. Biol. Chem., 235, $1820(1960)$.

22) J. E. Strickland and O. N. Miller, Biochim. Biophys. Acta, 159, 221 (1968).

23) S. Hueting, T. de Lange and D. W. Tempest, FEMS Microbiol. Lett., 4, 185 (1978).

24) W. Babel and K. H. Hofmann, FEMS Microbiol. Lett., 10, 133 (1981).

25) A. Ben-Amotz and M. Avron, FEBS Lett., 29, 153 (1973).

26) A. D. Brown and L. J. Borowitzka, in "Biochemistry and Physiology of Protozoa," ed. by M. Levandowsky and S. H. Hunter, Vol. 1, Academic Press, New York, 1979, p. 139. 